\title{
鴻之舞鉱業所の金銀青化製鍊
}

\section{Cyanidation of Gold and Silver Ores at Kohnomai Mine}

\author{
正会員森口義道
}

Yoshimichi MORIGUCHI

\section{1. 緒言}

鴻之舞鉣業所は北海道紋別市に所在し, 石北本線遠軽 駅または，名寄本線紋別駅よりそれぞれ約 $30 \mathrm{~km} の$ 地点 に位置する。

本鉣山䦿大正 4 年の発見にかかり，同6 年住友が買 山，開発に着手し，7年より湿式による金銀製錬を開始 した。

以降, 昭和 4 年元山第 1 鋕床の発見索初めとし, 俱知 晏内 5 号鉱床，元山第 2 鉱床等相つぐ鉱床の発見により 逐次製鍊設備の抾張を重ね，本邦最大の金山として昭和 17 年には日量 $3,000 \mathrm{t}$ 処理に達したが18年にいたり，金 山整備令により休山の止むなきにいたつた。

戦後，昭和23年より再開計画に着手し，24 年日量 400 tの青化製鍊設備の完成に伴心操業老開始し，その後数 次の拡張を経て 30 年には 1,400t/日に達したが，38年以 降操業規模の縮少合理化を行ない約 $700 \mathrm{t} /$ 日処理で現在 にいたつている。

人員は坑内外合計 530 名, そのらち製鍊関係は57名で 市。

\section{2. 鉱石の性 状}

錎床は浅熱水性含金銀石英方解石脈上りなり，現在稼 行中の主たるものは俱知安内 5 号, 藤島, 元山の各鉣床 である。

鉣石中の金は主としてエレクトラムとして存在し，銀 釯物核輝銀鉱の他，濃紅銀鉱，ポリバス鉣および一部ア ギラール鉱等を含み，金に対する銀倍率壮約16倍程度で ある。

随伴硫化鉱物は黄鉄鉱，白鉄鉱圭主とし，その他少量 の黄銅鉣，四面銅鉱，藍銅鉣，闺姍鉛鉣，方鉛鉣等が認 められる。

また脈不鉱物と乙ては, 石英, 王髄, 方解石, 水長石 およびカオリン，モンモリロナイト等の粘上鉣物がある。

鍁石特性は俱知安内 5 号等に対し, 藤島, 元山地区に おいては方解石を欠き, とくに藤島鉣は黒色泥岩确片を 含先微晶質石英よりなり，はなはだ緻密堅硬であり，含 有金属，鉱物も他に比し著しく微粒赾呈し，かつアンチ

* 住友金属鉣山株式会社鸿之舞鉣柴所

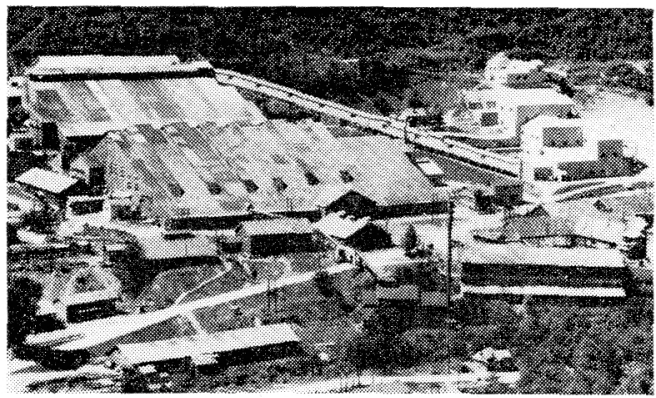

写真 1 鴻之舞鉱栄所青化䡛鍊工場全景

モン銀鉝物の比率が大であるとともに黄鉄鉣，白鉄鋅等 の含有もや小大で製錬処理が困難である。

製錬処理原銨の分析例を示せ放1表のようである。

第1表 慗鍊原鉱分析例

\begin{tabular}{r|r|r|r|r|r|r}
\hline \hline Au g/t & $\mathrm{Ag}$ g/t & $\mathrm{Cu} \%$ & $\mathrm{Zn} \%$ & $\mathrm{Fe} \%$ & $\mathrm{~S} \%$ & $\mathrm{Seg} / \mathrm{t}$ \\
\hline 6.1 & 102.4 & 0.002 & 0.029 & 2.00 & 0.57 & 16.8 \\
\hline $\mathrm{Mn} \%$ & $\mathrm{SiO}_{2} \%$ & $\mathrm{Al}_{2} \mathrm{O}_{3} \%$ & $\mathrm{CaO} \%$ & $\mathrm{MgO} \%$ & $\mathrm{Na}+\mathrm{K} \%$ & \\
\hline 0.12 & 84.73 & 2.87 & 4.44 & 0.13 & 0.30 & \\
\hline
\end{tabular}

\section{3. 操 業 概 要}

鉣石は全泥青化製錬法により Au5.7g/t，Ag94g/t 程 度の粗鉣圭日量 $700 \mathrm{t}$ 内外の処理を行ない金銀殿物とし て回収した後ささらに精金工程を経て精地金とする。

操業系統ならびに成績は第 1 図，第 2 表に揭げるとお りであるが，以下にその概要について述べる。

\section{$3 \cdot 1$ 受入, 破砕}

前記各鉝床より採掘された鈗石は坑内に設置したブレ ーキクラッシャでほぼ $120 \mathrm{~mm}$ 以下に破砕を行なつた後 ベルトコンベヤにより坑外に搬出され，製鍊原鉣として 破研場粗銍舎に受入れられるほか，一部露天採掘による 露頭周辺鉱石注ダンプカーにより直送される。

破砕は乾式処理で最大能力 $150 \mathrm{t} / \mathrm{h}$ 程度であるが，鉱 石特性に基き藤島，元山系とそれ以外の一般系に大別乙 て時間別運転により 2 系統処理を行ない両者の比率はほ ぼ1 : 1である。

受入鉱石はまずグリズリにより粉，塊に分けた後，塊 鉣は $914 \mathrm{~mm} \times 610 \mathrm{~mm}$ ブレーキタラッシャで約 $50 \mathrm{~mm}$ 以 
第 2 表操 業 成 績

\begin{tabular}{|c|c|c|c|c|c|c|c|c|c|c|c|c|c|c|c|c|c|c|}
\hline & \multirow{2}{*}{$\underset{\mathbf{t}}{\text { 製錬処理量 }}$} & \multicolumn{2}{|c|}{ 原鲐品位 $\mathrm{g} / \mathrm{t}$} & \multicolumn{2}{|c|}{ 尾鉣品位 $g / t$} & \multirow{2}{*}{$\begin{array}{c}\text { 殿物量 } \\
\mathrm{kg}\end{array}$} & \multicolumn{2}{|c|}{ 殷物品位 \% } & \multicolumn{2}{|c|}{ 青化実収率\% } & \multirow{2}{*}{$\begin{array}{c}\text { 精地金量 } \\
\mathrm{g}\end{array}$} & \multicolumn{2}{|c|}{ 精地金品位 $\%$} & \multirow{2}{*}{ 半製品量 } & \multicolumn{2}{|c|}{$\begin{array}{c}\text { 半慗品品位 } \\
\mathrm{g} / \mathrm{t}\end{array}$} & \multicolumn{2}{|c|}{ 精金実収率％ } \\
\hline & & $\mathrm{Au}$ & $\mathrm{Ag}$ & $\mathrm{Au}$ & $\mathrm{Ag}$ & & $\mathrm{Au}$ & $\mathrm{Ag}$ & $\mathrm{Au}$ & $\mathrm{Ag}$ & & $\mathrm{Au}$ & $\mathrm{Ag}$ & & $\mathrm{Au}$ & $\mathrm{Ag}$ & $\mathrm{Au}$ & $\mathrm{Ag}$ \\
\hline $\begin{array}{c}\text { 昭和 } 41 \text { /上 } \\
41 / \text { 下 }\end{array}$ & $\begin{array}{l}106,869 \\
104,437\end{array}$ & $\begin{array}{l}5.7 \\
5.5\end{array}$ & $\begin{array}{l}93.3 \\
94.5\end{array}$ & $\begin{array}{l}0.63 \\
0.55\end{array}$ & \begin{tabular}{|}
15.42 \\
13.10
\end{tabular} & $\begin{array}{l}14,682 \\
15,297\end{array}$ & $\begin{array}{l}3.68 \\
3.45\end{array}$ & $\begin{array}{l}56.66 \\
57.14\end{array}$ & \begin{tabular}{l|l}
6 \\
$\begin{array}{l}6 \\
4\end{array}$ & 88.90 \\
90.00
\end{tabular} & $\begin{array}{l}83.47 \\
86.14\end{array}$ & $\begin{array}{l}8,630,63 \\
8,722,56\end{array}$ & $\begin{array}{l}6.25 \\
5.83\end{array}$ & $\mid \begin{array}{r}93.50 \\
93.25\end{array}$ & $\begin{array}{l}11,000 \\
11,040\end{array}$ & $\begin{array}{l}398.2 \\
286.7\end{array}$ & $\begin{array}{l}19,689 \\
16,707\end{array}$ & $\begin{array}{l}99.13 \\
99.38\end{array}$ & $\begin{array}{l}96.30 \\
96.02\end{array}$ \\
\hline
\end{tabular}

（注）以上の他, 副産物として金属セレン $654 \mathrm{~kg}(41 /$ 上), $597 \mathrm{~kg}(41 /$ 下 $)$

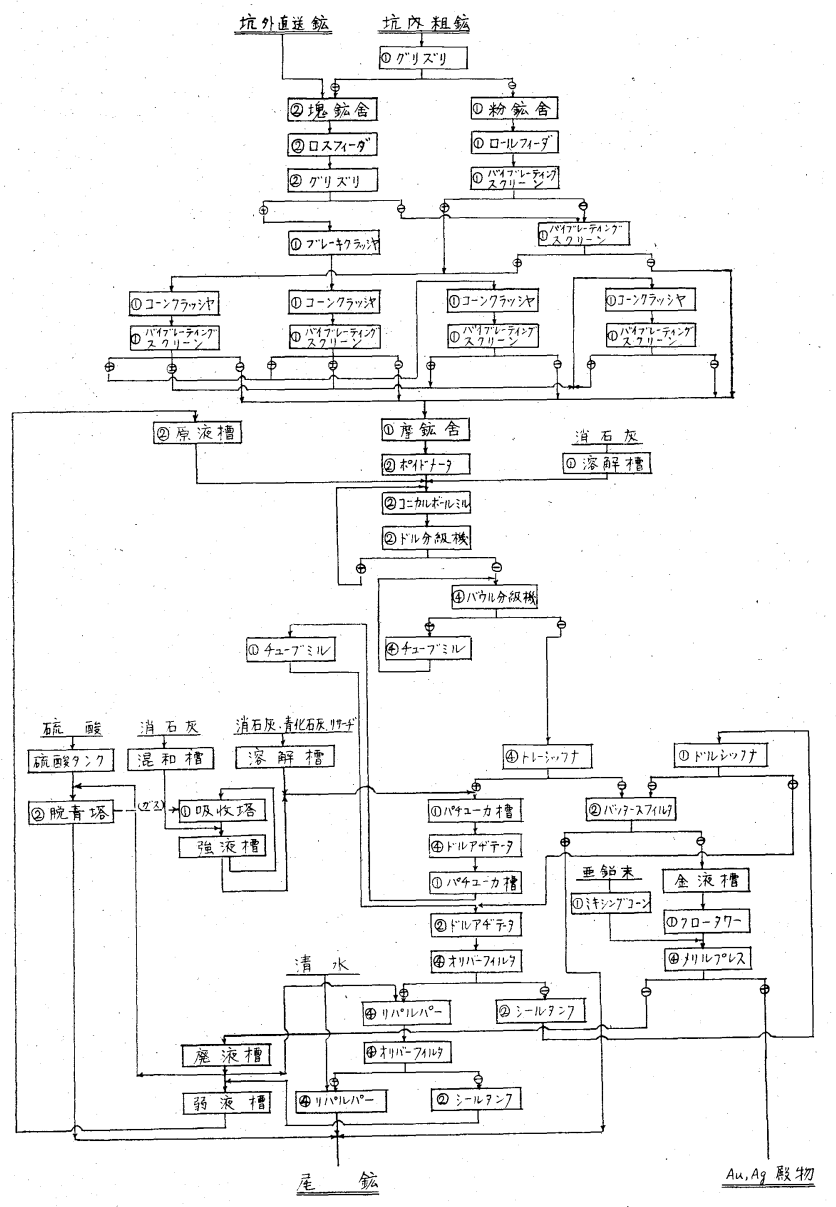

第1図製鍊操業系統図 $(700 \mathrm{t} /$ 日)

下に粗砕を行ない，また粉鉱は 2 台のバイブレーティン グスクリーンを経て $14 \mathrm{~mm}$ 以下の除去を行なつた後，そ れぞれ中砕工程に送られる。

中挽は 4 台のコーンクラッシヤ $(1,650 \mathrm{~mm} \phi \times 3$ 台, $1,200 \mathrm{~mm} \phi \times 1$ 台) とバイブレーティングスクリーンとの 閉回路操業により最終的に $14 \mathrm{~mm}$ 以下に破砕の上，前記 粉鉱網下鉱とともに摩鉱舎に送鉱されミル原鉱とする。

\section{$3 \cdot 2$ 摩鉱}

摩鉱は湿式 2 段摩鉱法により最終産物粒度 $-200 \mathrm{mesh}$ 約 $95 \%$ 程度に微粉砕を行なう。

ミル原鉣は消石灰の適量とともに，2台のコニカルボ ールミル $(2,400 \mathrm{~mm} \times 1,200 \mathrm{~mm})$ とドル分級機との閉 回路操業で 1 次摩鉱を行ない-200mesh $30 \%$ 内外に粉
砕の上，バウル分級機 4 台に配分，給 鉱さ れ，それぞれチューブミル $(1,800 \mathrm{~mm} \phi \times$ $4,800 \mathrm{~mm}, 1,800 \mathrm{~mm} \phi \times 3,600 \mathrm{~mm})$ との閉回 路で 2 次摩鉱を行ならが, 前述鉱石特性の差 異に基き系統別処理を行ない，とくに藤島， 元山系の微粉砕化に留意する他， $1,800 \mathrm{~mm} \phi$ $\times 4,800 \mathrm{~mm}$ チューブミル 1 台をアトリッシ ヨンミルとして使用する。

なお，摩鉱系統における使用水はすべて青 化工程よりの繰返し水を用いる。

\section{$3 \cdot 3$ 青 化}

摩鉱産物はパルプ濃度 11 12\%程度である のでこれを 4 台のトレーシックナ $(12,200$ $\mathrm{mm} \phi \times 3$ 台, $13,700 \mathrm{~mm} \phi \times 1$ 台) で約 $48 \%$ 程度 に濃縮の上コンディショナに給鉱され，ここ で消石灰，青化石灰，リサージ等の薬品添加 を行なつた後, $9,750 \mathrm{~mm} \phi \times 7,925 \mathrm{~mm}$ ドルア ヂテータ 6 基シリースで約 60 時間の攪拌溶解 を行ならが,ここの間においてさらにチュー ブミルによるアトリッション処理を行ならこ とにより溶解の促進向上を計つている。

溶解終了後のアヂテータ排泥は $4,880 \mathrm{~mm} \phi$ オリバーフィルタでの 2 段沪過法により沪 過, 洗浄を繰返し最終ケークはリパルピング の上，尾鉱として廃棄する。

一方, 金銀濃度の高い 1 次オリバーフィル タ沪液とトレーシックナオーバーフローの一 部はバッタースフィルタにより再度沪過清浄 を行ない，さらにクロータワーで脱酸素の後，亜鉛粉末 を添加してメリルプレスに圧入し金銀等を置換沈殿せし めた上で沪過, 分別する。

また，プレス廃液はオリバーフィルタケークの洗浄等 に使用する他，一部は弱液と合して摩鉱用水 (原液) と して使用する。

第 3 表 工程別溶解率の一例

\begin{tabular}{|c|c|c|c|c|c|}
\hline \multirow[b]{2}{*}{ 区 分 } & \multicolumn{2}{|c|}{$\mathrm{Au}$} & \multicolumn{3}{|c|}{$\mathrm{Ag}$} \\
\hline & $\%$ & 積 算 \% & $\%$ & 積 算 & $\%$ \\
\hline 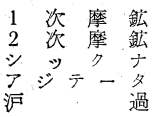 & $\begin{array}{r}25.0 \\
28.3 \\
6.0 \\
29.6 \\
1.6\end{array}$ & $\begin{array}{l}53 . \overline{3} \\
59.3 \\
88.9 \\
90.5\end{array}$ & $\begin{array}{r}7.3 \\
11.8 \\
7.8 \\
55.9 \\
2.4\end{array}$ & $\begin{array}{l}19 . \overline{1} \\
26.9 \\
82.8 \\
85.2\end{array}$ & \\
\hline
\end{tabular}


第 4 表 各種液中薬品濃度

\begin{tabular}{|c|c|c|c|}
\hline 種 別 & $\begin{array}{l}\mathrm{F} \\
\mathrm{NaCN}\end{array}$ & $\begin{array}{l}\mathrm{T} . \\
\mathrm{NaCN}\end{array}$ & $\mathrm{CaO}$ \\
\hline 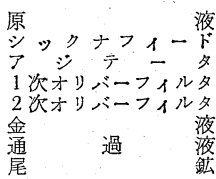 & $\begin{array}{l}0.043 \% \\
0.046 \\
0.074 \\
0.064 \\
0.052 \\
0.061 \\
0.056 \\
0.005\end{array}$ & $\begin{array}{l}0.046 \% \\
0.061 \\
0.100 \\
0.070 \\
0.056 \\
0.087 \\
0.064 \\
0.008\end{array}$ & $\begin{array}{l}0.045 \% \\
0.042 \\
0.038 \\
0.040 \\
0.026 \\
0.041 \\
0.049 \\
0.003\end{array}$ \\
\hline
\end{tabular}

第 6 表 昭和37年以降操業成績の推移

\begin{tabular}{|c|c|c|c|c|c|c|c|c|}
\hline \multirow[b]{2}{*}{ 年/期別 } & \multirow{2}{*}{$\begin{array}{c}\text { 処理釷量 } \\
\mathbf{t}\end{array}$} & \multirow{2}{*}{$\begin{array}{c}\text { 藤 島 鉱鉱比率 } \\
\%\end{array}$} & \multirow{2}{*}{$\begin{array}{c}\text { 摩鉱産物 } \\
\text { 粒度 } \\
(-200 \mathrm{M}) \\
\%\end{array}$} & \multicolumn{2}{|c|}{ 原鉣品位 } & \multicolumn{2}{|c|}{ 尾鉣品位 } & 溶 解 率 \\
\hline & & & & $\begin{array}{l}\mathrm{Au} \\
\mathrm{g} / \mathrm{t}\end{array}$ & $\begin{array}{l}\mathrm{Ag} \\
\mathrm{g} / \mathrm{t}\end{array}$ & $\begin{array}{l}\mathrm{Au} \\
\mathrm{g} / \mathrm{t}\end{array} \mid$ & $\begin{array}{l}\mathrm{Ag} \\
\mathrm{g} / \mathrm{t}\end{array}$ & Au $\%$ Ag \% \\
\hline 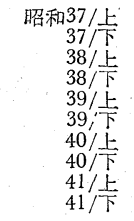 & $\begin{array}{l}200,569 \\
195,797 \\
133,918 \\
111,227 \\
112,381 \\
118,332 \\
107,088 \\
109,623 \\
106,869 \\
104,437\end{array}$ & $\begin{array}{r}1.3 \\
10.9 \\
20.1 \\
29.0 \\
27.6 \\
27.1 \\
31.7 \\
32.9 \\
34.5\end{array}$ & $\begin{array}{l}86.9 \\
86.4 \\
87.1 \\
83.4 \\
82.0 \\
81.1 \\
79.3 \\
79.3 \\
89.9 \\
94.1\end{array}$ & $\begin{array}{l}4.9 \\
4.8 \\
5.8 \\
5.8 \\
5.9 \\
5.7 \\
5.8 \\
5.8 \\
5.7 \\
5.5\end{array}$ & \begin{tabular}{r|}
86 \\
86 \\
95 \\
99 \\
101 \\
96 \\
99 \\
97 \\
93 \\
95
\end{tabular} & $\begin{array}{l}0.39 \\
0.3 \\
0.4 \\
0.6 \\
0.66 \\
0.65 \\
0.66 \\
0.74 \\
0.63 \\
0.55\end{array}$ & $\begin{array}{l}15.7 \\
14.7 \\
15.0 \\
17.3 \\
18.1 \\
19.0 \\
18.2 \\
18.6 \\
15.4 \\
13.1\end{array}$ & \begin{tabular}{|l|l|}
93.18 & 83.17 \\
93.04 & 82.91 \\
92.43 & 84.51 \\
90.47 & 82.37 \\
88.83 & 82.04 \\
88.57 & 80.25 \\
88.62 & 81.53 \\
87.31 & 80.75 \\
88.90 & 83.47 \\
90.00 & 86.14
\end{tabular} \\
\hline
\end{tabular}

第 5 表 精金産物分析表

\begin{tabular}{|c|c|c|c|c|c|c|c|}
\hline$\%$ & $\mathrm{Au}$ & Ag & $\mathrm{Cu}$ & $\mathrm{Pb}$ & $\mathrm{Zn}$ & $\mathrm{Fe}$ & $\mathrm{S}$ \\
\hline 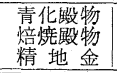 & $\begin{array}{l}3.67 \\
3.67 \\
6.08 \\
\end{array}$ & $\begin{array}{l}63.15 \\
63.07 \\
93.42 \\
\end{array}$ & $\begin{array}{l}0.19 \\
0.22 \\
0.178 \\
\end{array}$ & $\begin{array}{l}3.63 \\
3.43 \\
0.032\end{array}$ & $\begin{array}{c}10.26 \\
14.04 \\
0.006\end{array}$ & $\begin{array}{l}0.29 \\
0.19 \\
0.010\end{array}$ & $\begin{array}{l}0.49 \\
0.42 \\
0.003 \\
\end{array}$ \\
\hline & $\mathrm{Se}$ & $\mathrm{SiO}_{2}$ & $\mathrm{Al}$ & $\mathrm{Ca}$ & $\mathrm{Mg}$ & $\mathrm{Na}+\mathrm{K}$ & \\
\hline $\begin{array}{l}\text { 青化殿物 } \\
\text { 接焼殿物 } \\
\text { 精 地 金 }\end{array}$ & $\begin{array}{l}5.01 \\
0.80 \\
0.017\end{array}$ & $\begin{array}{r}3.83 \\
2.78 \\
\end{array}$ & $\begin{array}{r}0.28 \\
0.40 \\
-\end{array}$ & $\begin{array}{r}2.71 \\
3.02 \\
-\end{array}$ & $\begin{array}{r}0.02 \\
0.02 \\
-\end{array}$ & $\begin{array}{r}0 . \overline{96} \\
0.83 \\
-\end{array}$ & \\
\hline
\end{tabular}

第 3 表は各工程別の金銀溶解率，第 4 表は各液中薬品 濃度の一例を示す。

\section{$3 \cdot 4$ 精 金}

以上により回収した青化殿物は Au 3.6\%，Ag56\%， Se $5.0 \%$ 程度を含有するがこれを焙燒炉の余熱で乾燥 後，4 基のロータリーキルン $(456 \mathrm{~mm} \phi \times 2,500 \mathrm{~mm})$ に より $700 \sim 750^{\circ} \mathrm{C}$ で焙焼を行ない含有するセレンを $\mathrm{SeO}_{2}$ として飛散せしめた上，熔剤として硼砂・玨砂を配合し 傾転式熔解炉において $1,100 \sim 1,200^{\circ} \mathrm{C}$ でカラミ分離を 行ない，さらに黒鉛ルツボで再熔解精製の上アノード鋳 型に鋳込む。

精地金法品位 $\mathrm{Au} 6.5 \%, \mathrm{Ag} 92.5 \%$ 程度で別子鉱業所 電錬工場へ輸送する。

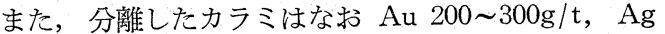
$15,000 \sim 20,000 \mathrm{~g} / \mathrm{t}$ 含有するので国富製錬所に売鉱す る。

焙焼炉で飛散せしめた $\mathrm{SeO}_{2}$ は昇華塔およびコット レル収塵機で捕収した後, 純水溶解, 沪過, イオン交換 精製を行ない，不純物を除去した亜セレン酸溶液に $\mathrm{SO}_{2}$ ガスを通じて金属セレンに還元し，水洗，粉挽，乾燥の 上用途に応じ粒状または粉状セレンとして市販する。製 品純度 Se $99.9 \%$ 以上である。

第 5 表に精金産物の品位分析例を揭 げる。

\section{4. 操業の改善}

最近数年間における製錬操業成績の 推移は第 6 表に掲げるように，昭和 38 年以降逐次低下の傾向を迻つている。

この原因を考察すると鉱石性状の項 で述べたように，主として藤島鉱床の
開発に伴いその性状の特異性に基く溶解不良に起因する ものとみなされ，処理比率の増大とともに顕著な摩鉱度 の低下と尾鉣品位の上昇を示し，溶解成績との間にほぼ 明瞭な相関性が認められる。

以下これに対処するため実施中である 2,3 の事項につ いて概要を述べる。

\section{$4 \cdot 1$ 摩鉱操業法の改善について}

青化尾鉱中に逸損する金銀の状態についてはその含有 率が微量であるため直接的にこれを確認することは極め て困難であるが，構成粒度別にいかなる品位分布を示す かについての一例を示すと第 7 表のようであり粗粒部に かたよりを示すことがほぼ明らかである。これらより尾

第 7 表 尾鉱粒度分布打よび品位

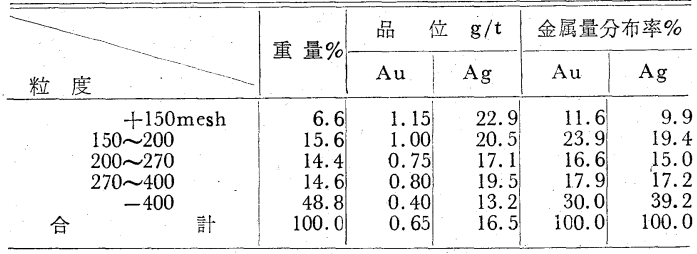

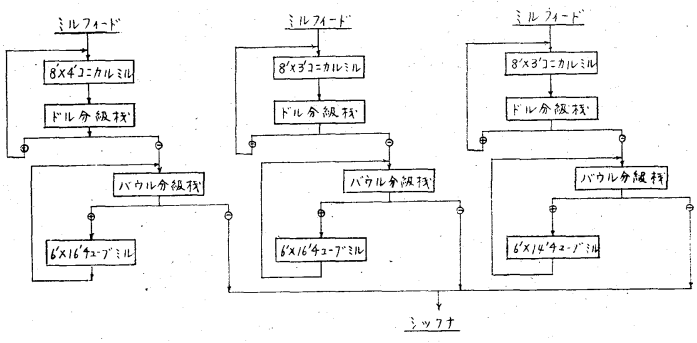

第2-1図 摩 鈗 系 統 (変更前) 


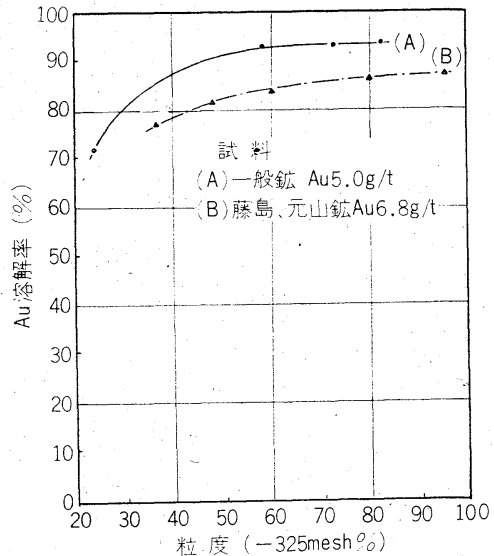

鉱中の比較的粗粒部を分離再摩鉱の上，青化処理を行な らとかなり顕著な溶解性を示す点から，その主たるもの は脈石中に包裡された片刃によるものと推定される。

以上のような観点から昭和 41 年 6 月以降，現行のよう に摩鉱操業形式の変更を行ない 2 次摩鉣の強化を計つた 結果，ほぼ明膫な粉砕度の上昇とともに摩鉣操業の安定 性も増大し，これに伴ら溶解成績の向上はランニングコ ス卜を充分カバーし得る結果をもたらせた。第 2 図に変 更前後の系統を示す。

さらに, 上記細摩鉱処理に加え, 鈗石特性に適応した 予備処理といら観点から，42年 1 月以降, 取扱い鈗石を 溶解性の差異に基き 2 グループに大別して系統別処理を 実施中である。

第 3 図は系統別鉱石の相対溶特性の一例を示し，これ らより藤島，元山系については -325 mesh 約70\%，一 般系については60\%を経済操業の基準としている。

\section{$4 \cdot 2$ 青化工程における溶解促進について}

䚓拌溶解工程における金銀の溶解進行過程について検

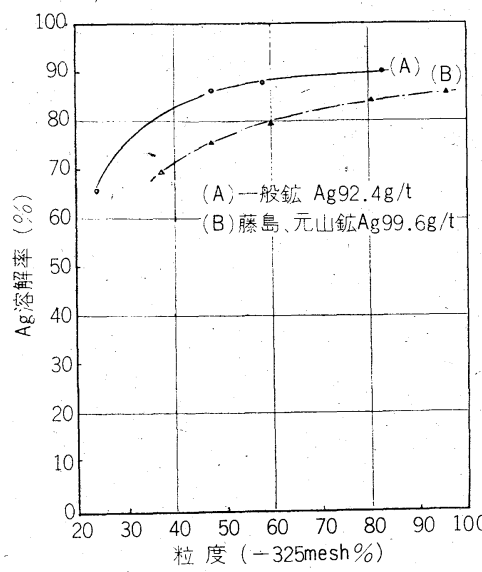

第 3 図

系統別相刘溶解率

討した結果，高濃度パルプによるアジテータの機能は必 ずしも満足すべきものとはみなされ難い点があり，これ を補いさらに溶解促進効果を計るため， 42 年 2 月より本 工程の中間にチューブミル, サイクロン等を組入れ, 残存 する薬品を積極的に活用して高濃度青化液中での Attrition と Regrinding を加味することにより尾鉱品位の 低下に努めている。

以上の総合結果はなお満足すべきものとはいい難い が，難処理鉱石の漸増傾向にかかわらず操業成績の低下 をカバーしつつ現在にいたつている。

\section{5. 結一言}

以上当鈗業所における青化製鍊操業と成績向上対策の 一端について概要を記述したが，今後さらに増大が予想 される難処理釷の合理的処理法については，まだ充分確 立されておらず，引続きこの基本的解明を推進するとと もに，総体的に老朽化した設備の集約合理化と管理方式 の改善に努力したい所存である。

\section{大谷鉱業所の金銀青化製錬}

\section{Cyanide Process of Gold and Silver Ores in Oya-Mine}

正会員 中 島 基 彦*
Motohiko NAKAJIMA

\section{1. 緒言}

大谷鉱業所は他の金山の例にもれず漸次粗鉱品位の低 下を示し，引続く金価格の低廉はおもむくところ人員， 設備の合理化と処理鉱量の増加によつて品位低下を補い

\footnotetext{
* 大谷釷山株式会社社長兼大谷釷業所所長
}

つつあるのが現状である。

昭和37年10月日本鉱業株式会社の直系より離れ子会社 の大谷鉱山株式会社として発足以来， $5,000 t /$ 月 を目標 とする粗砕，摩鉣系統の改造を行ない，昭和39年10月こ れを完成した。また国内では前例のない青化鉱さいの坑 内スライム充塡を昭和 40 年 4 月より実施し, 多大の効果 